\title{
EVALUASI PASKA HUNI ASPEK PERILAKU DI KANTOR KECAMATAN MANTRIJERON KOTA YOGYAKARTA
}

Suastiwi Triatmodjo*

Right now the District Office is a governmental office that has an increasing important role in giving services and generating regional income. To develop its service perfomance, the District Office has an intention to rearrange the interior design of the office building, therefore they need to do post-occupancy evaluation research. This research concentrates on the behavioural aspect. The basic assumption of this reasearch is that the built-environment is designed to fulfill the needs of human life as effectively as possible, whereas human effectiveness in any activity is greatly influenced by social and psychological factors. Thereby the success of an interior design does not only depend on technical, functional and aesthetic considerations, but also on behavioural consideration. This research has found typical behaviours which need to be considereded carefully in the planning and design of the District Office interior in the future.

\section{Key words: district office, interior, behaviour}

Kantor Kecamatan adalah kantor pemerintah yang memberikan pelayanan langsung kepada masyarakat serta menjadi titik penghubung antara pemerintah dengan masyarakatnya. Pada era otonomi daerah dewasa ini, kedudukan kantor kecamatan menjadi semakin penting terkait dengan kepentingan pemerintah memberi pelayanan kepada masyarakat dan upaya menumbuhkan pendapatan daerah dari pelayanan tersebut. Oleh karena itu kantor kecamatan harus dapat memberikan pelayanan yang cepat dan memuaskan kepada masyarakatnya. Hal ini terkait dengan bagaimana kriteria pelayanan yang baik itu, termasuk di dalamnya kriteria kualitas lingkungan atau ruang dan fasilitas lain dimana pelayanan tersebut diberikan.

Kantor Kecamatan Mantrijeron sebagai bagian dari Pemerintah Kota Yogyakarta, telah menempati gedungnya yang sekarang sejak tahun 1960-an, dan sudah direnovasi beberapa kali. Dalam rangka meningkatkan kinerja pelayanannya kepada masyarakat Kantor Kecamatan Mantrijeron bermaksud untuk menata ulang interior gedungnya. Untuk itulah evaluasi paska huni terhadap gedung harus dilakukan untuk mengetahui kinerjanya sekarang ini dan memastikan kebutuhan kinerja gedung yang seperti apa yang diinginkan oleh para pemakainya.

Dalam siklus pengembangan ilmu perancangan lingkungan hidup manusia, Evaluasi Pascahuni (Post Occupancy Evaluation) ini memegang peranan yang cukup penting. Penelitian ini dilakukan untuk mengetahui akibat-akibat dari keputusan yang dibuat di masa lalu; di fase pemrograman, desain dan implementasi, dan yang terpenting Evaluasi Pascahuni (EPH) dimaksudkan untuk menilai kinerja lingkungan kerja yang telah selesai dibuat dan telah dihuni, apakah kinerjanya telah sesuai dengan kebutuhan penghuninya, dan untuk perbaikannya di kemudian hari.

*Korespondensi penulis dialamatkan ke Program Studi Desain Interior, Fakultas Seni Rupa, Institut Seni Indonesia Yogyakarta, Telp/Fax: +62 274417219 e-mail: stw_triat@yahoo.com 
Sebagai fokus penelitian, EPH dalam prakteknya terbagi dalam tiga aspek, yaitu; aspek Teknis, aspek Fungsi dan aspek Perilaku (Preiser, dkk, 1988). Penelitian yang dilakukan mencakup ketiganya namun artikel ini hanya menuliskan salah satu aspek saja yaitu perilaku. Aspek perilaku meliputi: Proxemics and Territoriality, Privacy and Interaction, Environmental Perception, Image and Meaning, Environmental Cognition and Orientation. Deasy dan Laswell mengatakan bahwa lingkungan hidup manusia dirancang untuk memenuhi kebutuhan manusia seefektif mungkin, sementara efektivitas manusia dalam setiap kegiatannya dipengaruhi oleh faktor sosial dan psikologisnya (Deasy \& Laswell, 1985:68).

Pembahasan dalam tulisan ini akan difokuskan pada: bagaimanakah perilaku pemakai di dalam gedung Kantor Kecamatan Mantrijeron menyangkut: proxemics \& teritoriality, privacy \& interaction, environmental perception, image \& meaning, environmental cognition \& orientation dan bagaimanakah standar kinerja aspek perilaku yang cocok untuk kantor kecamatan di Yogyakarta.

\section{BAHAN DAN METODE}

Respon manusia terhadap lingkungannya bergantung pada bagaimana individu itu mempersepsi lingkungannya. Beberapa teori yang berkaitan dengan persepsi manusia terhadap lingkungannya dan respon manusia terhadap persepsi itu, mengkaitkan lima hal yaitu: Proksemitas dan teritorialitas, Privasi, Persepsi manusia terhadap lingkungan, Citra dan makna ruang serta Kognisi manusia terhadap ruang.

Proksemitas atau dalam bahasa Inggris disebut proxemics adalah ilmu tentang ruang (space) sebagai media hubungan manusia (Holahan, 1982:274). Lewat ruang personal yang ia ciptakan pada waktu manusia berkomunikasi dengan orang lain, ruang personal yang tercipta ini ternyata menunjukkan tingkat hubungan manusia tersebut dengan manusia lain yang diajaknya berkomunikasi. Ruang personal (personal space) ini oleh Fisher didefinisikan sebagai suatu batas maya yang mengelilingi seseorang yang tidak boleh dilalui oleh orang lain (Fisher dkk, 1984:149).
Faktor yang langsung terkait dengan proksemitas adalah teritorialitas. Holahan mendefinisikan teritorialitas sebagai suatu pola tingkah laku yang ada hubungannya dengan kepemilikan atau hak seseorang atau sekelompok orang atas sebuah tempat atau suatu lokasi geografis. Pola tingkah laku ini mencakup personalisasi dan pertahanan terhadap gangguan dari luar (Holahan, 1982:235). Deasy dan Laswell mengatakan bahwa untuk teritorialitas perlu dibuat batas yang jelas diantara dua ruang atau meja kerja. Sedangkan untuk personalisasi ruang kerja ada beberapa hal : beri identitas, sediakan tempat penyimpannan terkunci, buat meja menghadapi arah datang orang, hindari konsentrasi lalu lintas, berikan kendali lokal terhadap cahaya dan panas, sediakan pemandangan lewat jendela, sediakan perlengkapan yang fleksibel, beri kelonggaran untuk personalisasi, dan beri kemudahan dalam membersihkan (Deasy dan Laswell, 1985:68)

Persepsi orang terhadap lingkungan berhubungan dengan bagaimana manusia merespon/menanggapi lingkungan hidup di sekitarnya dengan berusaha untuk mengerti dan menilainya. Dalam hal ini ada dua pendekatan yang bisa dipakai yaitu konvensional dan konstruktivis. Pendekatan konvensional menyebutkan bahwa ada rangsangan (stimulus) dari luar berupa cahaya, suara atau suhu yang ditangkap oleh sel-sel syaraf, terjadi pengindraan, sehingga manusia mengenali dan menilai obyekobyek. Pendekatan konstruktivis menganggap bahwa persepsi merupakan kumpulan pengindraan, sehingga apabila seseorang mengindra suatu obyek di depannya ia akan diorganisir, dikaitkan dengan pengalaman dan ingatan masa lalu dan diberi makna tertentu sehingga seseorang itu mengenalinya sebagai sesuatu, misalnya mobil.

Setelah manusia mengindrakan obyek yang ada disekitarnya, ia memproses dan timbulah makna tentang obyek tersebut, manusia telah mempersepsi lingkungannya. Persepsi ini selanjutnya menimbulkan reaksi sesuai dengan asas busur refleks. Bell dkk (1978:89) membuat skema reaksi sebagai berikut: manusia berinteraksi dengan lingkungan (obyek) menghasilkan persepsi 
seseorang tentang obyek tersebut. Jika persepsi itu tidak menimbulkan masalah terhadap orang tersebut maka ia dalam keadaan seimbang (homeostatis), bila persepsi tersebut bermasalah maka ia akan menimbulkan stress. Oleh karenanya, akan timbul tekanan dalam diri manusia yang kemudian memaksanya melakukan penyesuaian (coping) yang bisa berwujud dalam bentuk adaptasi, yang dilakukan oleh orang tersebut terhadap dirinya sendiri, dan adjustment, yang diberlakukan oleh orang terhadap obyek.

Citra dan makna lingkungan memiliki 2 pengertian yang berbeda. Dalam kamus The Collins English Dictionary "citra" diartikan sebagai representasi, gambaran, personifikasi, (psikologi) pengalaman mental tentang sesuatu yang tidak tampak secara langsung. Sementara "makna" adalah tafsiran nilai atau pesan inti, simbolik atau yang benar, (filsafat) pencerapan suatu ekspresi, konotasinya. Dalam berinteraksi dengan lingkungan hidupnya manusia juga menciptakan makna bagi apa yang telah diindrainya. Rapoport (1982:14) menyebutkan bahwa manusia bereaksi terhadap lingkungan buatan secara global dan afektif (rasa suka tidak suka) sebelum ia menganalisis dan mengevaluasinya dengan lebih detail. Citra dan makna menjadi faktor yang penting dalam perilaku dan terkait dengan perasaan manusia. la juga bervariasi dari satu orang dengan orang yang lain karena perbedaan preferensi, pengalaman dan schemata, oleh karenanya citra dan makna ini bersifat kultural (Rapoport, 1982:21; Mangunwijaya, 1988:36)

Sub-aspek perilaku dalam penelitian $\mathrm{EPH}$ yang terakhir adalah Kognisi dan orientasi ruang, yang dalam istilah lain yang sering juga dipakai adalah cognitive map. Down dan Stea (1973) menterjemahkan cognitive map sebagai proses yang memungkinkan kita untuk mengumpulkan, mengorganisasikan, menyimpan dalam ingatan, memanggil, serta menguraikan kembali informasi tentang lokasi relatif dan tanda-tanda tentang lingkungan geografis kita. Dengan peta kognitif ini manusia mengenali lingkungan hidupnya, mempunyai peta kognitif yang baik berarti mengenali lingkungannya dengan baik sehingga ia tidak mempunyai masalah dengan lokasi, jarak maupun komunikasi lingkungan yang lain.

Aspek perilaku pada riset EPH berkaitan dengan kegiatan dan kepuasan pemakai terhadap lingkungan fisiknya. Kepuasan ini terkait dengan kondisi manusiawi pemakainya, karena sifatnya manusiawi ia berhubungan dengan kesejahteraan psikologis, fisiologis dan sosial pemakai yang dipengaruhi oleh rancangan bangunannya.

Penelitian EPH pada dasarnya memiliki pola bertingkat. Tingkatan dalam penelitian EPH tersebut menurut Preiser dkk (1988:54) ada tiga yaitu: indikatif, investigatif dan diagnostik. Penelitian ini berada pada level diagnostik, yaitu tingkat penelitian yang paling tinggi dan kompleks. Investigasi pada level penelitian ini harus dilakukan secara menyeluruh dan dalam, berlangsung lebih lama dan dimaksudkan tidak hanya memperbaiki suatu fasilitas tertentu tetapi untuk memperbaiki kinerja suatu tipe bangunan tertentu. Pada level ini biasanya juga dilakukan suatu studi banding dengan obyek penelitian yang sama, di mana obyek pembanding ini dianggap mempunyai keunggulan. Pembanding dalam penelitian ini adalah Kantor Kecamatan di Kabupaten Kulonprogo.

Populasi yang diamati pada penelitian ini adalah seluruh pemakai gedung Kantor Kecamatan Mantrijeron Kota Yogyakarta, yaitu para pegawai dan tamu atau masyarakat yang mencari pelayanan di kantor kecamatan. Sampel ditarik secara random dengan distribusi yang merata, masing-masing golongan pemakai terwakili secara proposional. Secara kuantitas diambil $15 \%$ - $20 \%$ sampel dari seluruh pemakai gedung yang kurang lebih berjumlah 25 orang yang tetap dan yang sampel tidak tetap ada 20-30 orang per harinya.

Teknik pengumpulan data terdiri dari: studi pustaka, observasi langsung ditambah dengan pemotretan terhadap obyek yang diamati, kuesioner dan wawancara kepada sampel yang telah ditentukan. Sementara itu teknik analisisnya terdiri dari beberapa macam dan tahapan rating scale, semantic differential scale maupun statistik distribusi yang sederhana, tahapannya pertama menganalisis hasil observasi dan mencatat 
kondisinya, kemudian dilanjutkan dengan mentabulasi data hasil kuesioner dan wawancara. Kedua hasil analisis ini selanjutnya dikomparasikan dengan standar, dan data hasil studi banding, kemudian saling dihubungkan di antara variabel-variabel yang ada untuk dicari korelasi dan lebih jauh lagi kausalitasnya.

\section{HASIL DAN PEMBAHASAN}

Berkaitan dengan Proksemitas dan Teritori, ditemukan beberapa fakta di lapangan. Fakta-fakta tersebut lebih banyak direkam dengan foto dan sedikit data diperoleh lewat jawaban wawancara. Di empat Kantor Kecamatan yang diteliti tidak banyak hal-hal khusus yang ditemui berkaitan dengan ruang personal dan proksemitas. Hal yang khusus seperti yang ditemui di Mantrijeron, di ruang Nivo, penataan mejanya sesuai dengan jenis kelamin pemakai, satu deret meja untuk pegawai laki-laki dan satu deret yang lain untuk pegawai perempuan, pegawai perempuannya kebetulan semua memakai jilbab.

Pedagang asongan yang keliling ke kantor-kantor ternyata dapat ditemukan di tiga kecamatan di kota. Hasil wawancara mengatakan bahwa kedatangan mereka hampir tiap hari dengan orang dan dagangan yang berbeda. Hubungan atau komunikasi yang terjadi antara para pedagang dengan pegawai kantor ini membentuk 'jarak personal'. Hal ini menunjukkan sifat kegiatannya atau tingkat hubungan antar keduanya akrab atau informal. Lokasi yang dipakai untuk berdagang ini bisa di mana saja, baik di meja kerja, di ruang tunggu pelayanan umum, di selasar, maupun di halaman. Jenis dagangan yang sering ditawarkan adalah makanan (rutin/tiap hari), pakaian, kebutuhan rumah tangga yang lain.

Temuan lain yaitu di Kantor Kecamatan Wates, di ruang pelayanan umum, disediakan loket untuk pengurusan Kartu Tanda Penduduk, Kartu Keluarga, dll., namun dari pengamatan di lapangan tampak kecenderungan bahwa masyarakat yang mencari pelayanan tidak berkomunikasi lewat loket tapi lebih senang melongok ke dalam ruang lewat pintu. Demikian juga dengan pegawai Kecamatan untuk menanyai atau menjelaskan sesuatu kepada anggota masyarakat yang ke tempat tersebut cenderung ke luar ruangan dan berdiri atau duduk di dekat pelanggan mereka.

Hasil evaluasi menyebutkan bahwa proksemitas yang berlaku telah sesuai dengan standar sekalipun ada beberapa kekhususan seperti yang ditemukan di Kantor Kecamatan Mantrijeron, Wates dan lainlainnya. Kasus pemisahan area kerja perempuan dan laki-laki ada kemungkinan terjadi pula di tempat lain atau di waktu yang akan datang. Pemisahan yang terjadi di Kantor Kecamatan Mantrijeron ini merupakan kesepakatan di dalam unit yang bersangkutan. Kesepakatan-kesepakatan (pemisahan atau penyatuan) dalam bentuk lain bisa saja terjadi di tempat ini atau ditempat lain.

Kemunculan pedagang asongan di dalam kantor merupakan fenomena umum yang terjadi di kantor-kantor pemerintah, dan masih akan nampak sampai 5 tahun ke depan. Hal ini timbul karena banyaknya pedagang keliling atau pedagang informal, yang menawarkan dagangan dan di sisi lain banyak pegawai yang membutuhkan barangbarang yang mereka jual, hal ini juga didukung dengan minimnya fasilitas hidup yang diberikan kepada pegawai dan longgarnya peraturan di kantor-kantor ini. Jarak personal yang tercipta pada saat terjadi jual-beli atau tawar menawar terjadi karena sifat perdagangannya mendekati konsumen pribadi-pribadi, hubungan antara konsumen dan pedagang kemungkinan sudah akrab karena sering berhubungan, dan juga area yang tersedia adalah apa yang ada di tempat itu.

Hubungan antara pegawai dengan masyarakat yang mencari pelayanan di tempat tersebut biasanya dekat. Adanya istilah wonge dewe atau orang satu kecamatan, menyebabkan interaksi yang bersifat formal cenderung dihindari, apalagi di daerah pedesaan. Kedua-duanya akan lebih senang dan lebih nyaman kalau duduk berhadap-hadapan dan bertatap muka langsung. Apabila mempertimbangkan jumlah pencari layanan maka tipe layanan berhadapan langsung tersebut masih dapat mengakomodasikannya. Tipe layanan lewat loket, karena lebih formal dan terfokus, akan lebih cocok untuk jumlah pelayanan atau 
konsumen yang besar.

Beberapa rekomendasi tindakan yang didasarkan atas hasil evaluasi di atas adalah bahwa proksemitas harus tetap dijaga pada standar yang umum, jarak personal, jarak sosial dan jarak publik. Sedangkan pelayanan kepada pengunjung atau publik sebaiknya memakai jarak personal. Selain itu, pembuatan jarak atau pemisahan area diantara sub-kelompok sebaiknya diakomodasi selama pemisahan tersebut sudah menjadi kesepakatan kelompok dan tidak bersifat pembedaan perlakuan atau rasialis.

Teritorialitas lembaga Kantor Kecamatan selain ditunjukkan dengan pagar, papan nama juga ditunjukkan dengan kehadiran pendopo pada bagian depan. Empat Kecamatan yang disurvai semua ada pendoponya dan letaknya selalu di depan. Tanda teritorialitas lain adalah pagar dan papan nama, gapura, bahkan di Kantor Kecamatan Wates ada tambahan Arca Gupalanya.

Teritori yang terbentuk pada jabatannya di tas meja kerjanya, dengan tambahan simbol-simbol kenegaraan, seperti: foto presiden dan wakil presiden, Garuda Pancasila, serta umbul-umbul daerah. Sebagai personalisasi tempat, tandatanda teritorialitas pribadi-pribadi jarang ditemukan secara permanen. Sebaliknya, banyak ditemukan personalisasi yang bersifat non-permanen seperti peletakan file, tas, jaket atau barang-barang pribadi yang lain sebagai tanda bahwa tempat tersebut milik seseorang. Banyak pegawai mengatakan bahwa hal tersebut dilakukan karena semua penghuni kantor tersebut sudah sama-sama tahu bahwa tempat-tempat tersebut telah dimiliki oleh masing-masing individu. (lihat Tabel 1)

Tanda-tanda teritorialitas ditemukan mulai dari skala yang besar kompleks kantor kecamatan sampai pada unit kecil ruang kerja individu. Personalisasi area Kantor Kecamatan bervariasi mulai dari yang selalu ada, seperti: papan nama (seragam), joglo (seragam), dan pagar, sampai personalisasi area yang terbaru, yang sedang banyak

Tabel 1. Teritorialitas

\begin{tabular}{|c|c|c|c|c|c|c|}
\hline No & Pertanyaan & Jawaban pilihan & $\mathbf{M}$ & $\mathbf{D}$ & $\bar{K}$ & $\mathbf{W}$ \\
\hline \multirow[t]{3}{*}{1.} & \multirow[t]{3}{*}{ Tempat kerja } & $\begin{array}{l}\text { Berdekatan dlm satu } \\
\text { ruang }\end{array}$ & 88 & 100 & 83,3 & 87,5 \\
\hline & & Berjauhan dlm satu ruang & - & - & - & - \\
\hline & & Bekerja sendiri & 11 & - & 16,6 & 12,5 \\
\hline \multirow[t]{3}{*}{2.} & \multirow{3}{*}{$\begin{array}{l}\text { Keluasan tempat } \\
\text { kerja }\end{array}$} & Kurang luas & 72 & 40 & 33,3 & 62,5 \\
\hline & & Cukupluas & 16 & 60 & 66,6 & 37,5 \\
\hline & & Luas & 11 & - & - & - \\
\hline \multirow[t]{2}{*}{3.} & \multirow[t]{2}{*}{ Butuh ruangan luas } & $\mathrm{Ya}$ & 22 & 20 & 50 & 50 \\
\hline & & Tidak & 11 & 60 & 50 & 37,5 \\
\hline \multirow[t]{3}{*}{4.} & \multirow[t]{3}{*}{$\begin{array}{l}\text { Cara tandai meja } \\
\text { kerja }\end{array}$} & $\begin{array}{l}\text { Menaruh file atau benda } \\
\text { milik pribadi }\end{array}$ & & 60 & & \\
\hline & & $\begin{array}{l}\text { Menulisi sesuai jabatan/ } \\
\text { kode }\end{array}$ & & & & \\
\hline & & Sudah sejak dulu/tahu & & & & \\
\hline
\end{tabular}

Keterangan:

M:Mantrijeron, D:Danurejan, K:Kraton, W:Wates

keseluruhan komplek bangunan Kantor Kecamatan relatif sama. Sedangkan teritorialitas di dalam gedung untuk unit kerja dan pegawai pada umumnya bervariasi. Teritorialitas unit biasanya dengan papan nama di depan atau di atas pintu. Teritorialitas pejabat biasanya ditunjukkan dengan nama dibangun di kantor-kantor Kecamatan di kota Yogyakarta, yaitu gapura masuk halaman kantor. Penandaan yang dibuat ini digunakan untuk menunjukkan identitas diri dan memberi rasa aman kepada pemilik. Penandaan ruang kerja telah dilakukan oleh semua Kantor Kecamatan yang disurvai 
walaupun dalam bentuk yang bervariasi. Penandaan pada meja kerja pribadi jarang dilakukan kecuali pada meja para pejabat seperti Camat atau Sekretaris Camat. Identitas yang ingin dimunculkan masih terbatas pada pejabatnya dan identitas kelompok saja.

Personalisasi ruang kerja dan meja kerja tidak nampak dilakukan oleh para pegawai Kantor Kecamatan. Kondisi seperti ini dapat diartikan bahwa para pegawai ini tidak terlalu terikat secara emosional kepada kepada tempat kerjanya, sehingga mereka tidak perlu menaruh hal-hal yang sifatnya untuk menjaga kerahasiaan diri: anonimity, reserve dan not neighbouring. Selanjutnya perkembangan sikap seseorang terhadap privasi adalah bagian dari proses sosialisasi, ia sarat dengan nilai-nilai budaya (Van Meel, 1998: 56). (lihat Tabel 2)

Temuan di lapangan menunjukkan bahwa rata-rata tingkat privasi yang dibutuhkan adalah sedang, sesuai jawaban pada kuesioner atas pertanyaan tingkat privasi yang dibutuhkan dan pertanyaan keinginan akan tempat kerja yaitu yang berdekatan dalam satu ruangan. Kebanyakan tempat kerja ditata dalam kelompok, hampir

Tabel 2. Privasi

\begin{tabular}{|c|l|c|c|c|c|c|c|c|c|}
\hline \multirow{2}{*}{ No } & \multirow{2}{*}{ Kebutuhan akan Privasi } & \multicolumn{2}{|c|}{$\mathbf{M}$} & \multicolumn{2}{|c|}{$\mathbf{D}$} & \multicolumn{3}{|c|}{ K } & \multicolumn{3}{c|}{ W } \\
\cline { 3 - 11 } & & Ya & Tdk & Ya & Tdk & Ya & Tdk & Ya & Tdk \\
\hline 1. & Anonimitas & 38 & 61 & 100 & 20 & 50 & 0 & 50 & 50 \\
\hline 2. & Tidak dikenali secara akrab & 44 & 50 & 80 & 40 & 33 & 16 & 50 & 50 \\
\hline 3. & Tidak ingin ngobrol & 16 & 88 & 0 & 60 & 16 & 33 & 50 & 50 \\
\hline 4. & Menyendiri & 38 & 61 & 20 & 80 & 0 & 50 & 50 & 50 \\
\hline 5. & Menghindar dari pandangan & 44 & 55 & 0 & 60 & 0 & 33 & 25 & 75 \\
\hline 6. & Melakukan hal pribadi & 16 & 88 & 0 & 60 & 0 & 33 & 50 & 50 \\
\hline
\end{tabular}

Keterangan:

M:Mantrijeron, D:Danurejan, K:Kraton, W:Wates

pribadi pada tempat tersebut.

Dari uraian evaluasi di atas, perlu dilakukan beberapa tindakan, yaitu penciptaan area sosial untuk para pegawai di dalam lingkungan kantor untuk mengurangi gangguan di ruang kerja dan personalisasi Kantor Kecamatan yang mengarah kepada keseragaman sebaiknya dikurangi, seperti joglo, gapura, dan pagar. Personalisasi yang khas masing-masing kantor kecamatan bisa lebih dikembangkan. Hal lain yang perlu dilakukan adalah berupaya mendorong tumbuhnya personalisasi yang sifatnya pribadi pada ruang atau meja kerja para pegawai.

Penyelidikan terhadap aspek privasi dan interaksi didasarkan pada beberapa kriteria dari berbagai teori. Wirawan mendefinisikan privasi sebagai keinginan atau kecenderungan pada diri seseorang untuk tidak diganggu kesendiriannya (Wirawan, 1992:110). Privasi tergolong dalam dua jenis yang masing-masing terbagi lagi ke dalam 3 sub: Tidak mau diganggu secara fisik: solitude, seclusion, dan intimacy. Keinginan tidak ada pegawai yang bekerja sendirian di dalam ruangan kecuali pada ruang Camat. Jawaban yang didapat dari kuesioner yang berkaitan dengan privasi adalah sebagai berikut:

Dari pengamatan di lapangan dan jawaban pada kuesioner dan wawancara dapat disimpulkan bahwa kebutuhan pegawai terhadap privasi tidak terlalu tinggi. Keinginan para pegawai untuk bekerja bersama teman di dalam ruangan, tidak ada ruang kerja yang tertutup, dan keinginan untuk bertandang bila tidak ada pekerjaan adalah bukti bahwa mereka lebih senang ada temannya dari pada sendirian. Kondisi demikian memang khas budaya masyarakat timur, dimana pribadipribadi ini lebih terikat dengan komunitasnya dari pada kepada dirinya sendiri. Mereka lebih senang bekerja dan berbagi tempat kerja dengan teman dari pada bekerja sendirian di dalam ruang pribadi. Hal ini berbeda dengan masyarakat barat yang sangat mengutamakan kehidupan pribadi mereka. Literatur-literatur barat selalu menekankan bahwa seorang pekerja mestinya diberi ruang 
kerja sendiri yang memberinya cukup privasi, sehingga ia tidak terganggu dalam bekerja. Oleh karena itu, tindakan yang direkomendasikan adalah bahwa privasi bagi para pegawai di tempat kerja harus tetap dipelihara atau disediakan. Hal yang harus diperhatikan adalah seberapa tinggi kebutuhan kelompok pegawai tersebut. Tingkat kebutuhan tersebut bisa saja berbeda antara di kota dan di desa. Selain itu, tingkat privasi yang harus diciptakan pada ruang pejabat harusnya lebih tinggi dari tingkat privasi para pegawai biasa.

Berkaitan dengan interaksi yang terjadi, didapatkan beberapa temuan di lapangan, yaitu interaksi pegawai dengan pegawai, pegawai dengan tamu instansi lain, pegawai dengan warga masyarakat yang mencari pelayanan dan dengan masyarakat lain. Interaksi formal dan informal bisa terjadi di mana-mana di dalam kompleks bangunan kantor kecamatan. Interaksi secara formal ada di ruang kerja, ruang tamu, ruang pelayanan umum, dan ruang pertemuan / pendopo. Sedangkan secara informal, interaksi bisa terjadi di halaman dan di selasar ruang kerja.

Interaksi di luar kedinasan atau informal sering terjadi tiap hari di jam-jam tidak sibuk, biasanya setelah jam 11.00. Bentuk interaksi yang sering ditemukan adalah pegawai berbincang santai dengan pegawai lain, atau pegawai berinteraksi dengan pedagang asongan yang datang ke kantor.

Interaksi yang tercipta, baik formal maupun informal, dapat terjadi hampir di semua tempat di dalam komplek bangunan. Perubahan kebijakan kantor kecamatan yang menekankan pada pelayanan kepada masyarakat, sudah seharusnya mengubah pola interaksi pegawai dengan pengunjung, pengunjung akan diterima dengan sikap yang lebih ramah dan membantu. Perubahan yang nampak baru pada penyediaan fasilitas yang lebih baik bagi pengunjung.(lihat Tabel 3 )

Beberapa pola interaksi pada mulanya mungkin dianggap mengganggu tapi karena sudah terbiasa manusia kemudian menerimanya sebagai pola yang lazim, inilah yang disebut sebagai adaptasi. Adaptasi ini biasa terjadi pada baik pada interaksi formal maupun informal. Hal ini terjadi pada saat menerima kedatangan teman untuk mengobrol di ruang kerja atau pada saat kedatangan para pengasong barang

Tabel 3. Interaksi

\begin{tabular}{|c|c|c|c|c|c|c|}
\hline No & Pertanyaan & Jawaban pilihan & $\mathbf{M}$ & $\mathbf{D}$ & $\mathbf{K}$ & $\bar{W}$ \\
\hline \multirow[t]{2}{*}{1.} & \multirow[t]{2}{*}{ Cara melayani } & Berhadapan langsung & 88 & 100 & 83 & 100 \\
\hline & & Tidak berhadapan lgs & 11 & - & 33 & 37 \\
\hline \multirow[t]{3}{*}{2.} & \multirow{3}{*}{ Sepi pelayanan } & Berdiam diri & - & 20 & 16 & - \\
\hline & & Ngobrol & 61 & 80 & 16 & 12 \\
\hline & & Membaca & 33 & 40 & 16 & 62 \\
\hline \multirow[t]{2}{*}{3.} & \multirow[t]{2}{*}{ Di mana no. 2 terjadi } & Meja kerja masing2 & 61 & 60 & 50 & 100 \\
\hline & & Di ruang lain & 27 & 40 & 16 & - \\
\hline \multirow[t]{3}{*}{4.} & \multirow[t]{3}{*}{ Situasi saat bekerja } & Ramai & 16 & 40 & 16 & - \\
\hline & & Cukup ramai & 58 & 80 & 50 & 62 \\
\hline & & Sepi & 16 & 20 & - & 37 \\
\hline \multirow[t]{3}{*}{5.} & \multirow{3}{*}{$\begin{array}{l}\text { Konsentrasi } \\
\text { terganggu aktivitas } \\
\text { sekitarnya }\end{array}$} & $\mathrm{Ya}$ & 22 & 40 & 50 & 75 \\
\hline & & Tidak & 55 & 80 & 16 & 22 \\
\hline & & & & & & \\
\hline \multirow[t]{3}{*}{6.} & \multirow{3}{*}{$\begin{array}{l}\text { Privasi yang } \\
\text { dibutuhkan }\end{array}$} & Tinggi & 11 & - & - & - \\
\hline & & Sedang & 50 & 60 & 33 & 75 \\
\hline & & Rendah & 11 & 20 & - & 25 \\
\hline \multirow[t]{2}{*}{7.} & \multirow{2}{*}{$\begin{array}{l}\text { Apabila privasi } \\
\text { terganggu }\end{array}$} & Menegur & 22 & 40 & 16 & 87 \\
\hline & & Pergi menjauh & 38 & 40 & 16 & - \\
\hline \multirow[t]{2}{*}{8.} & \multirow{2}{*}{$\begin{array}{l}\text { Kegiatan semban } \\
\text { bekerja }\end{array}$} & & 38 & - & - & - \\
\hline & & & 27 & - & - & - \\
\hline
\end{tabular}

Keterangan:

M:Mantrijeron, D:Danurejan, K:Kraton, W:Wates 
dagangan. Adjustment hanya terjadi dalam jumlah yang kecil, dan pada hal-hal tertentu saja seperti privasi, perlindungan atau keamanan.

Berdasarkan evaluasi di atas, ada beberapa tindakan yang direkomendasikan, yaitu perlunya mengurangi terjadinya interaksi non-formal di ruang kerja dengan menyediakan area-area tersendiri yang bisa dipakai untuk interaksi non-formal. Selain itu, perlu pula disediakan tempat yang nyaman disertai sikap yang lebih ramah dalam melayani masyarakat.(lihat Tabel 4)

Temuan yang berkaitan dengan persepsi di lapangan menunjukkan bahwa dari beberapa kategori persepsi yang ditanyakan kepada para pegawai di keempat kantor kecamatan, pegawai di Kantor Kecamatan Mantrijeron cenderung mengatakan bahwa tiga ruang berikut, yaitu: Ruang Camat, Ruang Sekretaris Camat dan Ruang Pelayanan Umum itu sempit, padat, silau, bising, panas, udara berbau dan berdebu. Sementara itu di tiga kantor kecamatan yang lain para pegawainya cenderung mengatakan "tidak" untuk berlaku pada katagori-katagori tertentu seperti sempit, padat, silau dan panas. Bentuk adjustment yang bisa direkam adalah pemasangan gordijn, menaruh barangbarang di atas almari, dan memasang kipas angin.

Melihat temuan-temuan tersebut di atas dapat dikatakan bahwa proses interaksi manusia, dalam hal ini pegawai kantor kecamatan, dengan lingkungannya telah terjadi. Dalam interaksi tersebut muncul tekanan-tekanan kecil yang telah bisa diatasi dengan kemampuan adaptasi manusianya. Walaupun begitu Kantor Kecamatan Mantrijeron tampaknya menghadapi masalah yang lebih besar yang terlihat dari keluhan para pegawainya. Adaptasi sudah mereka lakukan tetapi tampaknya belum mampu mengakomodasi kebutuhan para pegawai.

Mengacu pada teori Wirawan bahwa persepsi manusia terhadap lingkungan itu relatif, dipengaruhi oleh sifat pribadi dan pengalaman masa lampaunya (Wirawan, 1992: 110), maka tidak adanya tekanan / stress pad para pegawai ini bisa terjadi karena mereka sudah terbiasa dengan

Tabel 4. Persepsi Pegawai terhadap Ruang Pelayanan Umum

\begin{tabular}{|l|l|c|c|c|c|c|c|c|c|c|}
\hline \multirow{2}{*}{ No. } & \multirow{2}{*}{ Keadaan } & \multicolumn{2}{|c|}{$\mathbf{M}$} & \multicolumn{2}{|c|}{$\mathbf{D}$} & \multicolumn{2}{|c|}{ K } & \multicolumn{2}{|c|}{ W } \\
\cline { 3 - 11 } & & Ya & Tdk & Ya & Tdk & Ya & Tdk & Ya & Tdk \\
\hline 1. & Sempit & $\mathbf{8 6}$ & 14 & $\mathbf{2 0}$ & - & $\mathbf{1 6}$ & - & $\mathbf{2 5}$ & - \\
\hline 2. & Padat & $\mathbf{1 0 0}$ & - & $\mathbf{2 0}$ & - & $\mathbf{1 6}$ & - & $\mathbf{2 5}$ & - \\
\hline 3. & Silau & $\mathbf{1 0 0}$ & - & - & $\mathbf{2 0}$ & $\mathbf{1 6}$ & - & $\mathbf{1 2}$ & $\mathbf{1 2}$ \\
\hline 4. & Bising & $\mathbf{6 7}$ & 33 & - & - & $\mathbf{1 6}$ & - & - & $\mathbf{1 2}$ \\
\hline 5. & Panas & $\mathbf{1 0 0}$ & 0 & - & - & $\mathbf{1 6}$ & - & $\mathbf{1 2}$ & - \\
\hline 6. & Udara berbau & $\mathbf{8 0}$ & 20 & - & - & $\mathbf{1 6}$ & - & - & $\mathbf{2 5}$ \\
\hline 7. & Tempat berdebu & $\mathbf{8 0}$ & 20 & - & $\mathbf{2 0}$ & $\mathbf{1 6}$ & - & $\mathbf{1 2}$ & - \\
\hline
\end{tabular}

Keterangan:

M:Mantrijeron, D:Danurejan, K:Kraton, W:Wates

pertanyaan tersebut.

Data dan pengamatan lapangan juga menunjukkan bahwa interaksi pegawai dengan tempat kerjanya telah menimbulkan permasalahan, yang ditunjukkan dengan adanya tindakan adaptasi pada ketiga ruang di empat kantor kecamatan. Bentuk adaptasi yang terekam adalah aktivitas kipas-kipas, mengubah arah duduk, menggeser perabotan, dan lain-lain. Sementara itu, untuk adjustment tidak semua ada dan hanya kondisi lingkungan yang ada di kantor, kondisi lingkungan di rumah sama dengan yang di kantor atau mereka tidak punya pembanding, lingkungan yang lebih baik.

Uraian evaluasi di atas menghasilkan beberapa rekomendasi tindakan, yaitu: perlunya dibuat gudang atau tempat penyimpanan sehingga barang-barang yang tidak diperlukan dapat disimpan. Penataan kembali ruang perlu pula dilakukan yang dibarengi dengan perancangan kembali 
perabot sehingga bisa didapatkan penataan yang ringkas. Selanjutnya, desain fisik bangunan atau interior yang akan datang harus lebih cermat mempertimbangkan keadaan ruang; sempit, padat, silau, bising, panas, udara berbau dan debu. Perancang harus memberi solusi yang lebih nyata dan terintegrasi terhadap masalah persepsi manusia ini.

Berkaitan dengan citra dan makna, ada beberapa teori yang dapat dijadikan sebagai kriteria unjuk kerja. Dalam berinteraksi dengan lingkungan hidupnya manusia juga menciptakan makna bagi apa yang telah diindrainya. Rapoport (1982:14) menyebutkan bahwa manusia bereaksi terhadap lingkungan buatan secara global dan afektif (rasa suka tidak suka) sebelum ia menganalisis dan mengevaluasinya dengan lebih detail. Citra dan makna menjadi faktor yang penting dalam perilaku dan terkait dengan perasaan manusia. la juga bervariasi dari satu orang dengan orang yang lain karena perbedaan preferensi, pengalaman dan schemata, oleh karenanya citra dan makna ini bersifat kultural (Rapoport, 1982:21; Mangunwijaya, 1988:36).

Dalam desain interior kantor Kleeman mengatakan bahwa ada banyak elemen desain kantor yang bersifat simbolis dan tidak selalu bersifat fungsional. Beberapa elemen tersebut adalah; ada tidaknya sesuatu, ukuran, kuantitas dan/atau kualitas ruang kerja, mebel, foto, plaket dan sebagainya (Kleeman, 1991:13). Elemenelemen ini menunjukkan bagaimana perilaku manusia dalam membentuk citra dirinya atau kantornya sehingga orang lain akan berperilaku tertentu terhadapnya.

Tanggapan reponden terhadap lingkungan kantor (Ruang Camat, Sekretaris Camat dan Pelayanan Umum) ditunjukkan dalam skala semantik yang terekam dari kuesioner, seperti tampak pada Tabel 5. Dari tabel itu tampak bahwa rata-rata reponden menempatkan pendapatnya pada posisi di tengah. Hanya sedikit sekali pegawai yang menyatakan pendapatnya secara ekstrim dengan nilai semantik bawah atau atas. Rentang nilai dari satu ekstrim ke ekstrim yang lain banyak dijumpai berasal dari responden di Kantor Kecamatan Mantrijeron.(lihat Tabel 5)

Skala semantik ditengah dengan kesan monoton kemungkinan terjadi karena mereka tidak berani mengatakan persepsi mereka yang sebenarnya, sehingga memilih nilai netral. Tetapi kondisi ini juga bisa dibaca bahwa nilai mereka memang itu, artinya dalam kehidupan sehari-hari mereka kondisi seperti yang ada di kantor kecamatan itulah

Tabel 5. Skala Semantik Ruang Camat

\begin{tabular}{|l|c|c|c|c|c|c|c|r|}
\hline & \multicolumn{7}{|c|}{ Skala nilai dan jumlah penilainya M, $\mathbf{~ , ~ K , ~ \& ~ W ~}$} & \\
\cline { 2 - 8 } & $\mathbf{1}$ & $\mathbf{2}$ & $\mathbf{3}$ & $\mathbf{4}$ & $\mathbf{5}$ & $\mathbf{6}$ & $\mathbf{7}$ & \\
\hline Sederhana & 5 & $\mathbf{2}$ & $2,2,1,1$ & $8,1,1,4$ & $1,-,-, 1$ & - & - & Kompleks \\
\hline Indah & 1 & - &,,,,---- & $9,1,2,4$ & $5,-,-, 2$ & 2 & 2 & Jelek \\
\hline Unik & - & - & $-,, 2,-, 1$ & $5,-, 1,4$ & $4,2,-, 2$ & 2 & 8 & Biasa \\
\hline Polos & 4 & -5 & $3,2,-,-$ & $5,2,1,2$ &,,,--- 4 & - & 1 & Berhias \\
\hline Menarik & 1 & - & $1,2,-, 2$ & $7,1,1,3$ & $8,1,-, 1$ & 1 & 2 & Membosankan \\
\hline Sempit & 2 & 1 & $4,-,-,-$ & $8,2,1,3$ & $1,1,-, 3$ & 2 & 1 & Luas \\
\hline Terbuka & 4 & 1 & $3,-,-, 1$ & $7,1,1,3$ & $3,2,-, 2$ & - & - & Tertutup \\
\hline Murung & - & 1 & $4,1,-,-$ & $11,2,1,2$ &,,,--- 3 & 2 & - & Ceria \\
\hline Mengundang & 4 & 1 & $3,1,-, 1$ & $8,1,1,2$ & $2,1,-, 1$ & - & - & Menolak \\
\hline Kacau & 4 & 2 & $6,-,-,-$ & $3,1,1,3$ & $-, 2,-, 2$ & 2 & 1 & Teratur \\
\hline Tidak nyaman & 2 & 2 & $7,-,-, 1$ & $5,1,1,2$ & $-, 2,-, 3$ & 1 & 1 & Nyamann \\
\hline Padat & 4 & 4 & $5,-,-,-$ & $3,-, 1,3$ & $-, 3,-, 2$ & 1 & 1 & Longgar \\
\hline Menyebalkan & 1 & 3 & $5,1,-,--$ & $6,1,1,2$ & $1,1,-, 3$ & 1 & 1 & Menyenangkan \\
\hline Bersih & 2 & - & $1,-,-,-$ & $11,2,1,3$ & $1,1,-, 3$ & 4 & 1 & Kotor \\
\hline
\end{tabular}

Keterangan:

M:Mantrijeron, D:Danurejan, K:Kraton, W:Wates 
yang mereka punyai, sehingga mereka tidak mempunyai referensi untuk mengatakan lebih baik atau lebih jelek.

Dalam membangun citra dan makna pada kantor kecamatan ini ada beberapa temuan, seperti pemasangan atribut formal gambar presiden dan wakil presiden, Garuda Pancasila, bendera Merah Putih, umbulumbul daerah, dan piala-piala yang pernah diraih. Atribut lain yang dipasang di dinding adalah data statistik kantor kecamatan, papan tulis yang menunjukkan acara atau kegiatan yang harus dijalankan oleh pejabat, ditambah beberapa kalender dengan gambar artis dan logo perusahaan pemberi kalender.

Hal lain yang teramati adalah budaya kantor pemerintah yang birokratis dan formal sangat terasa di dalam keempat kantor kecamatan ini. Gambar Presiden dan Wakil Presiden, umbul-umbul Daerah Tingkat II, piala-piala atau gambar statistik yang dipajang pada dinding dan almari menjadi lambang-lambang yang menunjukkan gambaran citra siapa mereka. Kalau membaca pada atribut-atribut fisik seperti desain perabot, bahan dan finishingnya maka citra yang muncul adalah belum terlalu modern dan berkelas menengah ke bawah.

Apabila Kantor Camat bermaksud mengedepankan citra pelayanan yang lebih baik kepada masyarakat maka Kantor ini perlu mengubah gambaran yang sudah ada, antara lain dengan menciptakan suasana yang lebih mengundang dan ramah yang bisa diwujudkan lewat perilaku pegawai dan elemen-elemen lingkungan. Selain itu, perlu dilakukan pengurangan simbol-simbol birokrasi pemerintahan.

Sub-aspek terakhir adalah kognisi dan orientasi. Kognisi dan orientasi ruang diterjemahkan sebagai proses yang memungkinkan kita untuk mengumpulkan, mengorganisasikan, menyimpan dalam ingatan, memanggil, serta menguraikan kembali informasi tentang lokasi relatif dan tanda-tanda tentang lingkungan geografis kita. Dengan peta kognitif yang baik manusia mengenali lingkungan hidupnya, sehingga ia tidak mempunyai masalah dengan lokasi, jarak maupun komunikasi lingkungan yang lain.

Sasaran pengamatan aspek kognisi dan orientasi ini ditujukan kepada para pengunjung kantor kecamatan, yaitu para warga yang datang mencari pelayanan kantor kecamatan. Hal ini mengasumsikan bahwa para pegawai kantor kecamatan tersebut telah mempunyai kognisi dan orientasi lingkungan yang baik terhadap komplek bangunan kantornya. (lihat Tabel 6)

Masalah kognisi dan orientasi lingkungan selalu dihadapi oleh orang-orang yang datang mengunjungi tempat baru, ini terjadi karena mereka memang tidak mempunyai informasi tentang lingkungan tersebut. Oleh karena itu desain lingkungan pada ruang publik harus bisa meringankan dan membantu masalah yang dihadapi oleh para pengunjung ini. Para pengelola gedung harus dapat memberikan kemudahan kepada para pengunjung yang datang ke tempat tersebut, dengan memberi penjelasan lengkap tentang gedung dan lingkungannya.

Dari evaluasi di atas, kantor kecamatan perlu untuk melakukan beberapa tindakan, yaitu menempatkan Ruang Pelayanan Umum di area yang strategis, mudah dilihat dan dituju, membuat peta

Tabel 6. Kognisi dan Orientasi Lingkungan Pengunjung

\begin{tabular}{|l|l|}
\hline Kantor Camat & $\begin{array}{l}\text { Data hasil amatan, wawancara dan kuesioner terhadap kognisi dan } \\
\text { orientasi pengunjung kantor kecamatan }\end{array}$ \\
\hline Mantrijeron & $\begin{array}{l}\text { Sering ditemukan para pengunjung kebingungan mencari letak ruang } \\
\text { pelayanan umum. } \\
\text { Para pegawai KC mengatakan bahwa sering harus menunjukan di mana } \\
\text { letak ruang pelayanan umum kepada para pengunjung. }\end{array}$ \\
\hline Danurejan & $\begin{array}{l}\text { Pengunjung menyebutkan merasa agak segan kalau masuk ke KC untuk } \\
\text { mencari pelayanan. }\end{array}$ \\
\hline Kraton & $\begin{array}{l}\text { Pengunjung mengatakan bahwa pelayanan di KC sudah cukup baik } \\
\text { tinggal ditingkatkan sedikit dengan papan penunjuk ruang. }\end{array}$ \\
\hline Wates & $\begin{array}{l}\text { Tidak ada data yang terekam tentang kognisi dan orientasi lingkungan } \\
\text { para pengunjung. }\end{array}$ \\
\hline
\end{tabular}


lingkungan, "You are here", untuk membantu para pengunjung memahami lingkungan yang dikunjunginya, dan menyediakan resepsionis di area masuk sehingga bisa membantu para pengunjung yang ingin menemukan tempat yang ditujunya.

Pada akhirnya, penelitian ini menghasilkan beberapa kesimpulan. Perilaku para pemakai gedung berkaitan dengan Sub-aspek Proksemitas dan Teritorialitas dapat dikatakan normal. Untuk proksemitas kondisi normal ini harus dijaga, pelayanan kepada pengunjung sebaiknya memakai jarak personal. Perlu ada area sosial untuk mengurangi tekanan atau invasi teritori di dalam ruang atau meja kerja. Kemauan untuk menandai teritori perlu ditumbuhkan diantara para pegawai tapi dikurangi penandaan teritori yang sifatnya seragam.

Privasi dan Interaksi, perilaku pengguna gedung terhadap sub-aspek ini adalah rendah bahkan pegawai cenderung mengatakan lebih senang bekerja dengan ada temannya dari pada bekerja sendiri di dalam ruang. Latar belakang budaya menjadi faktor yang mempengaruhi kebutuhan akan privasi ini. Walaupun begitu privasi pegawai dalam bekerja harus tetap dijaga, untuk pegawai yang mempunyai jabatan tingkat privasinya akan naik sejajar dengan jabatannya. Interaksi yang terjadi di kantor bersifat formal dan informal, pemisahan area yang jelas untuk kedua interaksi ini tidak dijalankan secara ketat, beberapa interaksi non formal terjadi di ruang kerja. Ke depan kantor kecamatan perlu menyediakan area untuk interaksi non formal. Dengan harapan dengan cara ini produktivitas kerja pegawai naik, karena selama bekerja ia tidak diganggu dengan aktivitas non formal.

Persepsi para pegawai terhadap

Ruang Camat, Ruang Sekretaris Camat dan Ruang Pelayanan Umum cenderung positif sementara pegawai Kantor Kecamatan Mantrijeron cenderung mengatakan negatif pada semua indikator yang ditanyakan. Pertentangan ini bisa terjadi karena masalah persepsi ini menurut para ahli bersifat relatif tergantung sifat pribadi dan pengalaman masa lalu manusianya. Untuk perancangan interior kantor kecamatan, masalah persepsi penggunanya tetap harus diperhatikan dan diperbaiki.

Sub-aspek berikutnya adalah Citra dan Makna. Skala semantik yang digunakan dalam penelitian ini untuk mengetahui citra dan makna ruang yang dipunyai para pengguna gedung ternyata tidak efektif. Kebanyakan pengguna memberikan nilai tengah untuk semua indikator yang ditanyakan. Sekalipun demikian, citra dan makna kantor kecamatan dapat terbaca melalui simbol dan tanda-tanda yang dapat ditemukan di dalam gedung. Citra sebagai kantor pemerintah yang birokratis masih sangat kental terbaca. Oleh karena itu, untuk mendukung program pelayanan prima kepada masyarakat maka kantor kecamatan perlu menumbuhkan citra yang lebih ramah kepada para pencari pelayanan, dan mengurangi kesan formal birokratif.

Kognisi dan Orientasi lingkungan merupakan sub-aspek yang hanya diteliti pada pengunjung kantor kecamatan. Penelitian telah menunjukan bahwa para pengunjung ini ternyata tidak mempunyai kognisi dan orientasi lingkungan yang baik terhadap masing-masing kantor kecamatan. Beberapa warga harus bertanya dulu untuk dapat menemukan tempat pelayanan yang akan ditujunya. Perancangan kantor kecamatan sebagai bangunan publik perlu memperhatikan kondisi ini dan harus memberikan cukup penjelasan tentang gedung mereka sehingga pengunjung atau publik bisa mempunyai kognisi dan orientasi yang baik terhadap gedung tersebut.

Beberapa saran yang disampaikan ditujukan untuk perbaikan secara keseluruhan, tidak detail ke masing-masing sub-aspek. Hasil penelitian ini menunjukkan bahwa kelemahan yang ditemukan pada hampir semua kinerja aspek dan sub-aspek gedung ini terjadi karena beberapa sebab, yaitu: pertama adanya perubahan kebutuhan pemakai gedung. Kedua Perencanaan dan perancangan awal interior gedung Kantor Camat tidak matang. Ketiga standar biaya yang disediakan untuk pembangunan gedung termasuk rendah. Keempat Bagian Rumah Tangga Kantor Camat, yang bertanggung jawab terhadap pengelolaan gedung, tidak berfungsi secara optimal. Kelima perencanaan dan perancangan bangunan tidak memakai konsultan ahli, terutama 
LINTAS

RUANNG | VOL.2 | EDISI 2 | 2008

interiornya.

Saran lain yang berkaitan dengan penerapan hasil penelitian ini untuk perbaikan pada Kantor Kecamatan Mantrijeron maupun Kantor Camat yang lain adalah: pertama, perlu dilakukan penelitian yang lebih detail dan teliti mengenai kebutuhan para pemakai gedung, sehingga dapat menyusun program kebutuhan yang lebih dapat diandalkan. Kedua, prinsip utama dalam perbaikan lingkungan ini adalah memberi kemudahan kepada para pemakai gedung untuk beraktivitas di dalamnya, sehingga dapat meningkatkan produktivitas pegawai dan pelayanannya kepada masyarakat dapat optimal.

\section{DAFTAR PUSTAKA}

Altman, Irwin. 1975. The Environment and Social Behavior. MONTEREY: Brooks/Cole Publishing Co.

Bartuska, Tom J., \& Gerald, L. Young. (eds). 1994. The Built Environment. MENLO PARK: Crisp Publication, Inc.

Bell, Paul. 2001. Environmental Psychology. ORLANDO: Harecourt College Publisher.

Ching, F. D. K. 1979. Architecture: Form, Space and Order. NEW YORK: Van Nostrand Reinhold Co.

1987. Interior Design Illustrated. NEW YORK: Van Nostrand Reinhold Co.

Deasy, C.M. \& Lasswell, Thomas E. 1985. Designing Places for People. NEW YORK: Whitney Library of Design.

Hall, Edward T. 1969. The Hidden Dimension. NEW YORK: Anchor Books Doubleday \& Co, Inc.

Holahan, C.J. 1982. Environmental Psychology. NEW YORK: Random House

Kleeman, Walter B. Jr. 1983. The Challenge of Interior Design. NEW YORK: Van Nostrand Reinhold Co.

Lawson, Bryan. 2001. The Language of Space. OXFORD: Architectural Press.

Mangunwijaya, Y.B. 1988. Wastu Citra. JAKARTA: PT Gramedia.

Preiser, Wolfgang F.E., Rabinowitz, H.Z., \& White, E.T. 1988. Post Occupancy Evaluation. NEW YORK: Van Nostrand Reinhold Company, Inc.

Rapoport, A. 1982. The Meaning of The Built Environment. BEVERLY HILLS: Sage Publications.

Sukmana, Oman. 2003. Dasar-dasar Psikologi Lingkungan. MALANG: Bayu Media dan UMM Press.

Wasistiono, Sadu, (ed). 2002. Menata Ulang Kelembagaan Pemerintah Kecamatan. BANDUNG: Pusat Kajian Pemerintahan STPDN dan Citra Pindo.

Wirawan S., Sarlito. 1992. Psikologi Lingkungan. JAKARTA: PT. Gramedia.

Zimring, C.M., \& J. E. Reizensteiner. 1981. A Primer on Post Occupancy Evaluation. The American Institute of Architect's Journal, Vol 70. 52-58. 